\begin{tabular}{|l|c|c|c|c|}
\hline $\begin{array}{l}\text { Cuadernos de Investigación Geográfica } \\
\text { Geographical Research Letters }\end{array}$ & 2019 & N $^{\circ} 45(1)$ & pp. 143-165 & eISSN 1697-9540 \\
\hline
\end{tabular}

\title{
THE NEED TO UNDERSTAND THE CULTURAL BIOGRAPHIES OF ALPINE AND SUBALPINE LANDSCAPES DURING LATER PREHISTORY: UPLAND ARCHAEOLOGY IN THE CANTABRIAN MOUNTAINS
}

\author{
D. GONZÁLEZ-ÁLVAREZ*
}

\begin{abstract}
Institute of Heritage Sciences, Consejo Superior de Investigaciones Científicas (Incipit, CSIC),
\end{abstract} Avda. de Vigo, s/n, 15705 Santiago de Compostela, Spain.

\begin{abstract}
Current debates around the Anthropocene tend to focus on recent planetary-scale processes. However, regional and small-scale processes can be very telling about human agency in the shaping of landscapes overtime. Indeed, anthropogenic impacts of different intensities can be observed on landscapes since Prehistory - even in such remote and allegedly marginal areas as deserts, wetlands or mountains. In this article, I reflect on the longterm anthropization of alpine and subalpine areas in the western area of the Cantabrian Mountains (North-West of Iberia) in Later Prehistory. Studying the earlier anthropogenic pressure on upland environs in this period reminds us of the potential of landscape archaeology to enhance interdisciplinarity in debates about the Anthropocene. With the aim of emphasizing the role of archaeology as a mediating arena between social sciences, humanities and earth sciences, I analyse the scarce archaeological information available for upland landscapes of this study area to show how these datasets can nuance evolutionary interpretations of paleo-environmental sequences studied at natural deposits. Only through integrated and comprehensive discussions around the cultural and environmental traits of landscapes will we be able to fully understand the complex social contexts where agrarian labour and collective action shaped the alpine and subalpine areas in the Cantabrian Mountains since the spread of the Neolithic.
\end{abstract}

La necesidad de comprender las biografías culturales de los paisajes alpinos y subalpinos durante la Prehistoria reciente: Arqueología de alta montaña en la Cordillera Cantábrica

RESUMEN. Los debates actuales sobre el Antropoceno suelen estar centrados en procesos de escala planetaria, mientras procesos a menor escala pueden mostrarnos mucha información sobre la capacidad de acción humana en la formación de los paisajes a lo largo del tiempo. De hecho, se pueden observar impactos antropogénicos con diferentes intensidades desde la Prehistoria, incluso en áreas 
remotas o pretendidamente marginales como los desiertos, las zonas pantanosas o las montañas. En este trabajo, se reflexiona sobre el proceso diacrónico de antropización de las zonas alpinas y subalpinas del área occidental de la Cordillera Cantábrica (Noroeste de Iberia) durante la Prehistoria reciente. Estudiando la más temprana presión humana sobre los ambientes altimontanos en este período podemos reclamar el potencial de la Arqueología del Paisaje como estímulo para la interdisciplinariedad en los debates acerca del Antropoceno. Con el ánimo de enfatizar el papel que la Arqueología puede desempeñar como ámbito para la mediación entre las Ciencias Sociales, las Humanidades y las Ciencias de la Tierra, se examina la escasa información arqueológica disponible en los paisajes de alta montaña del área de estudio para mostrar cómo estos datos pueden matizar las interpretaciones evolucionistas de las secuencias paleoambientales estudiadas en depósitos naturales. Sólo a través de discusiones integradas y comprehensivas sobre los complejos contextos sociales en los que el trabajo agrario y la acción colectiva modeló las áreas alpinas y subalpinas en la Cordillera Cantábrica a partir de la expansión del Neolítico.

Key words: Landscape Archaeology, Anthropocene, cultural landscapes, pastoralism, anthropization.

Palabras clave: Arqueología del Paisaje, Antropoceno, paisajes culturales, pastoreo, antropización.

Received: 31 October 2018 Accepted: 9 December 2018

*Corresponding author: David González-Álvarez, Instituto de Ciencias del Patrimonio, Consejo Superior de Investigaciones Científicas (INCIPIT, CSIC). Avda. de Vigo, s/n, 15705 Santiago de Compostela, Spain. E-mail address: david.gonzalez-alvarez@incipit. csic.es

\section{Introduction}

During the $35^{\text {th }}$ International Geological Congress (2016) held at Cape Town (South Africa), the Anthropocene was accepted as a new geological era, as proposed by the 'Working Group on the Anthropocene' within the International Commission on Stratigraphy. (http:/quaternary.stratigraphy.org/working-groups/anthropocene/, last access: 14/08/2018). The decision contributed to highlight this recent concept among the general public, as was then widely reflected by the mass media. (e.g. Carrington, 2016; Salas, 2016). The Anthropocene had been a relevant matter of academic discussion since the label was launched at the beginning of the new millennium (Crutzen and Stoermer, 2000). In the following years, the concept gained enormous momentum in science, its use spreading from geologists, bio-scientists and geographers to scholars within different branches of the social sciences and humanities, including archaeology. In fact, several review articles appeared in some of the most relevant interdisciplinary journals (Crutzen, 2002, 2006; Finney, 
2016; Lewis and Maslin, 2015; Waters et al., 2016; Zalasiewicz et al., 2010), and periodical titles entirely devoted to the Anthropocene were soon established - such as Anthropocene (Elsevier, from 2013), Elementa: Science of the Anthropocene (BioOne, from 2013), or The Anthropocene Review (SAGE, from 2014). Discussions around this topic have helped raise public awareness about sustainability and human impact on the environment. As a result, different academic disciplines have been able to renew some of their traditional standpoints regarding the 'nature/culture divide' (Ingersn, 1994), and these lively debates have strengthened interdisciplinary collaborations.

Most of the academic disputes around the Anthropocene and related public discussions in the mass media seem to imply that the concept is mainly a matter of interest to earth sciences. However, many scholars in the social sciences and humanities have long been reflecting on the Anthropocene and the cultural and social processes attached to the concept - also in archaeology (e.g. Lane, 2015; Solli et al., 2011). Some authors have described the concept in a thicker or more comprehensive way than its initial definitions, emphasizing the cultural and social implications that should be taken into account, and considering different chronological starting points for the appearance of this geological period (Braje, 2015; Edgeworth et al., 2015). Meanwhile, other scholars -such as Philippe Descola (2005), Bruno Latour (2013), Donna Haraway (2015) or Jason Moore (2016)- have claimed that the spread of this concept might neutralize public perceptions about the impacts caused on Earth by capitalism, neoliberalism and globalization. Regrettably, these critiques do not enjoy as much visibility for wider audiences yet, but for rare exceptions (e.g. FernándezDurán, 2011 for Spain).

What contribution could archaeologists make to this ongoing loud conversation, and what can we learn from it? Human communities have mediated in the evolution of landscapes as a result of the long-term impact caused by productive activities such as pastoralism, agriculture, forestry, mining, hunting and gathering. These subsistence strategies aimed at granting social reproduction are tightly related to different societies' particular political, religious or cultural traits (Criado-Boado, 1993; Ingold, 1993). Reflecting on the archaeological research of cultural landscapes in NW Iberia during Later Prehistory, I will analyse how (allegedly) 'marginal' or 'liminal' landscapes -such as alpine and subalpine environments in the western area of the Cantabrian Mountains- have been shaped by diverse human agencies throughout history. Some of these changes were deep and sudden, resulting in enduring transformations. Other variations were subtler and only faintly reflected on ancient landscapes. Moreover, some of these historical changes were attached to large-scale processes, although other variations may reflect regional or local patterns. So, would it be useful in our particular study area to distinguish the impact of the Anthropocene as a discrete process, disregarding when that process began? Or should we skip that simplistic view and focus instead on the political, cultural and productive contexts that frame interrelations between human groups and their surrounding environs in the longue durée? 


\section{Unravelling landscape biographies in upland environments}

Archaeology can inform us about the political, cultural and productive frameworks that have layered out cultural landscapes throughout different historical periods (CriadoBoado, 1993). In order to address this larger debate, I will consider how people shaped upland landscapes in the western Cantabrian Mountains since the spread of agricultural and pastoralist activities between the Neolithic (ca. 6000 BP) (Cubas-Morera et al., 2016; Fano-Martínez et al., 2015; López-Merino et al., 2010) and the expansion of the Roman state in this area (ca. 2000 BP) (Marín-Suárez and González-Álvarez, 2011; Sastre, 2001). By doing this, I aim to blur disciplinary boundaries between social and natural sciences, and to emphasize the role of landscape archaeology as a theoretical and methodological ground for transdisciplinary mediation. Therefore, I will emphasize the need to unravel the cultural and social traits attached to the Anthropocene in relation to the debate addressed in this volume.

Drawing from the theoretical and methodological framework of landscape archaeology (Anschuetz et al., 2001; Criado-Boado, 1999; David and Thomas, 2008; Thomas, 2001), I seek to understand the relationships established by human communities with their surrounding environment in mountainous areas of NW Iberia during Later Prehistory (González-Álvarez, 2019). This way, I intend to build a long-term narrative on the cultural biographies of upland landscapes considering archaeological, paleoenvironmental and ethnographic datasets (González-Álvarez, 2016). I will also draw on historical ecology as a useful frame from the social sciences, to interrelate those diverse proxies as I aim to understand the role of societies in the making of cultural landscapes (Armstrong et al., 2017; Crumley, 1994). In fact, recent discussions in archaeology have addressed the relevance of human activities in the formation of European landscapes, even in allegedly 'marginal' upland areas (Carrer, 2013a; Costello and Svensson, 2018; Gassiot-Ballbè et al., 2014; Rendu, 2003; Walsh, 2014). Collaborations and interdisciplinary dialogues with paleo-environmental studies have been fundamental in building these approaches (López-Sáez et al., 2006; Mazier et al., 2009; Orengo et al., 2013; Walsh et al., 2006), while the observation of ethnographic references is extremely useful as a source for interpretative stimuli (Carrer, 2013b; González-Álvarez et al., 2016; González-Ruibal, 2003). Cultural, socio-political, and productive traits from Later Prehistoric societies have also been considered in order to generate solid narratives in the light of anthropological and sociological reflections on cultural landscapes (Bender, 1993; Hirsch and O'Hanlon, 1995; Ingold, 2000; Johnson, 2007).

\section{Case study: The western area of the Cantabrian Mountains}

The Cantabrian Mountains form an outstanding geographical unit in north-western Iberia. These mountains have conditioned the production strategies, settlement patterns and mobility systems of the societies inhabiting this region. In fact, communications and cultural contacts between different regions in the vicinity of these elevated territories have been both limited and enabled by them throughout history. In this paper, I will focus on these mountains' western area, comprising the stretch of this mountain chain that corresponds to the current regions of Asturias and León (Fig. 1). 


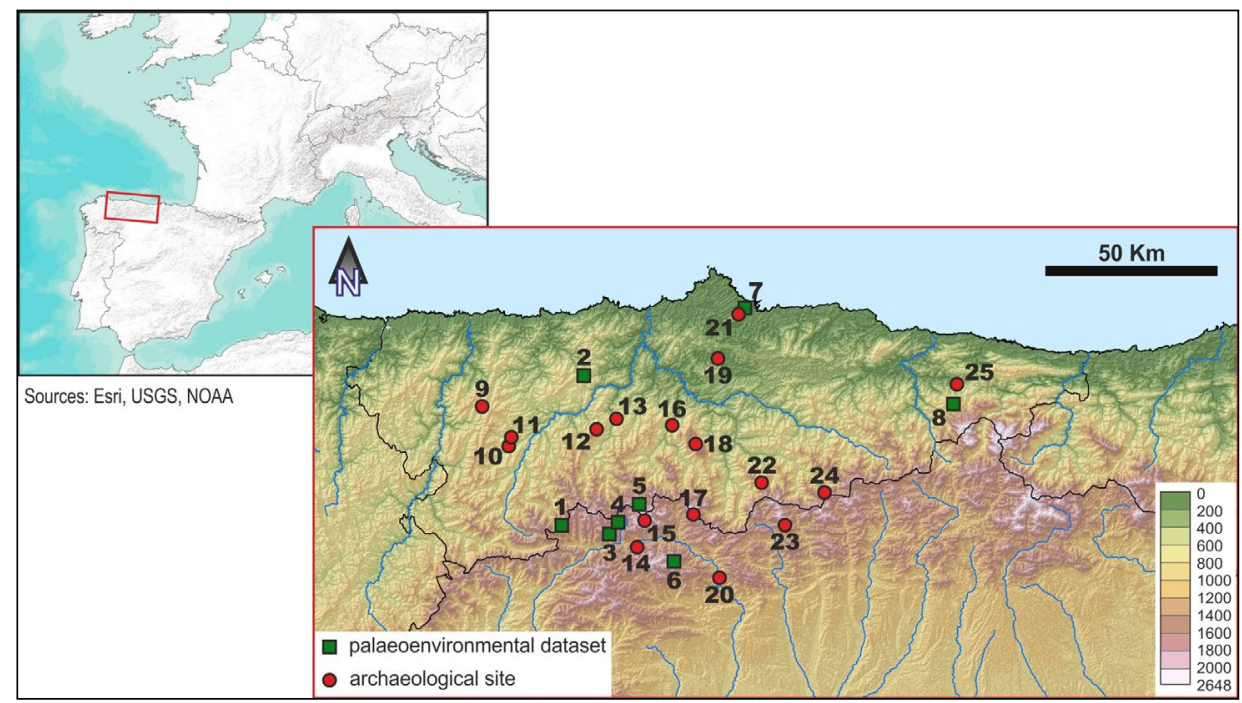

Figure 1. Location of the study area and the sites mentioned. Palaeoenvironmental datasets: 1: Lleitariegos; 2: La Molina; 3: El Castro lake; 4: La Mata; 5: El Valle lake; 6: Laguillín; 7: Monte Areo; 8: Enol lake. Archaeological sites: 9: Carondio megalithic complex; 10: Almoñu; 11: San Chuis; 12: Vigaña; 13: El Monte la Caimada; 14: El Pico Sulcastro; 15: Las Verdes; 16: Villanueva de Santu Adrianu; 17: Peña Ubiña; 18: L'Aramo; 19: La Torca'l Arroyu; 20: Los Barrios de Luna castle; 21: Monte Areo megalithic complex; 22: El Mayéu de Busián; 23: La Profunda; 24: Puerto Gumial; 25: El Milagro.

Unfortunately, the study area has been clearly underexplored by previous archaeological research. In fact, these mountains constitute one of the most outstanding voids in our knowledge about Later Prehistory in the Iberian Peninsula. In addition to the usual problems for the development of archaeological research in upland areas, the Cantabrian Mountains became some sort of frontier or liminal area between different scholarly traditions. Thus, the region could be considered as a 'no man's land' between those scholars studying Later Prehistory in the Cantabrian region (Arias-Cabal and Armendáriz, 1998; de Blas and Fernández-Tresguerres, 1989; González-Morales, 2012; Villa-Valdés, 2007), and those who focusing on the Duero basin (Celis, 1996; Delibesde Castro and Fernández-Manzano, 1983-1984; Garrido-Pena et al., 2012; HerránMartínez, 2008) - with a few exceptions (Díez-Castillo, 1996-1997; Marín-Suárez, 2011a). Therefore, the development of new research in the area arises as one of the most urgent needs for Iberian archaeology.

The northern watersheds between the highest peaks of the western area of the Cantabrian Mountains (which are over 2600 m a.s.l.) and the Cantabrian Sea form narrow and deep valleys with an oceanic climate. Verticality is one of the most relevant geographical traits there, where significant altitudinal variations allow local communities to exploit different nearby biotopes following seasonal patterns. To the South, this mountain range faces the gentler plain landscapes of the Duero basin with an elevation of around 900-1000 $\mathrm{m}$ a.s.l. and a Continental Mediterranean climate. Indeed, high altitudes and extreme weather 
conditions become limitations for human mobility across the mountains. But, on the other hand, alpine and subalpine grasslands have been outstanding summer attractions for shepherds from both sides of the mountain range at different historical periods (Abarquero et al., 2009; Fernández-Mier et al., 2013; García-Martínez, 2003; González-Álvarez et al., 2016; Jimeno, 2001), in addition to the rich mineral sources of copper and iron ores at some locations (Argüello-Menéndez, 2008; de Blas and Suárez-Fernández, 2010). As a result, seasonal movements for exploiting those valuable resources intensified relations and contacts between human groups coming from different areas in North-Western Iberia (González-Álvarez, 2013; Vázquez-Varela, 2001) (Fig. 2).

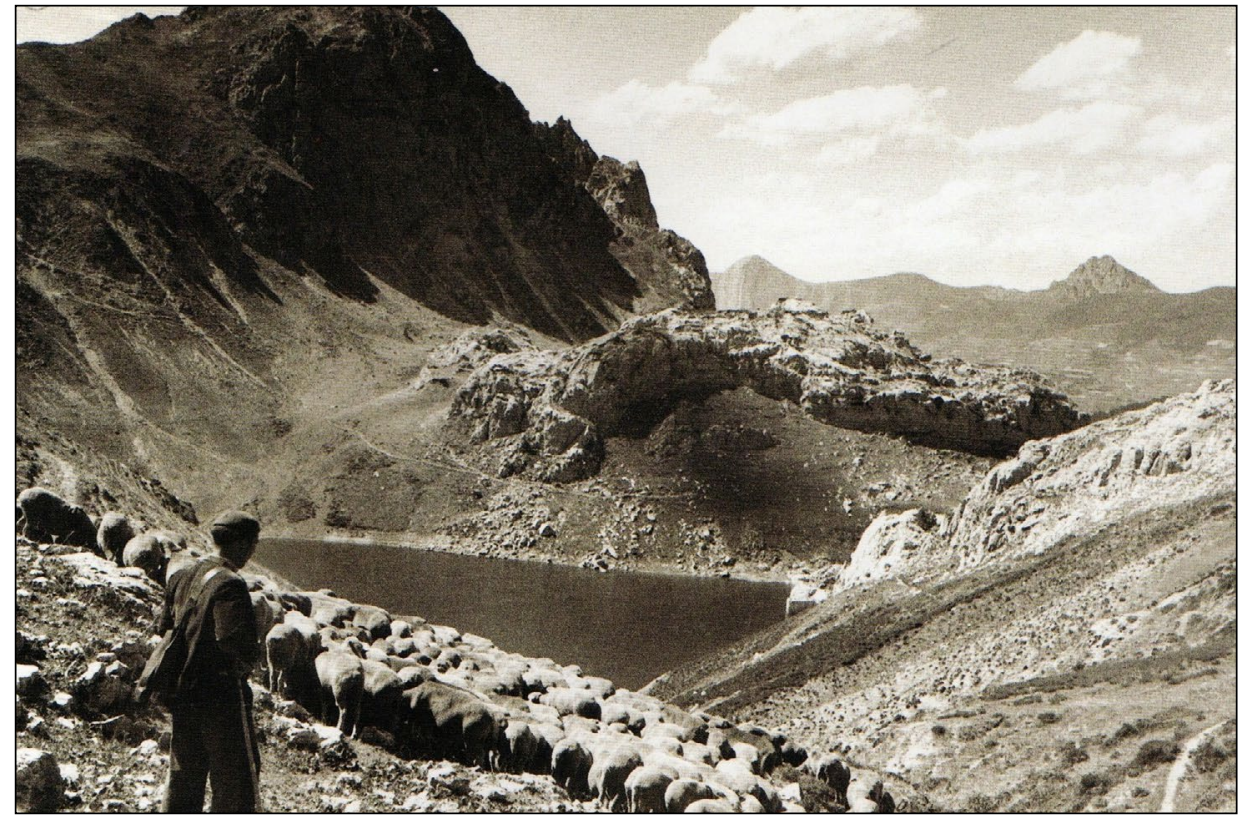

Figure 2. Merino shepherd with a flock of sheep near La Cueva lake (Somiedu, Asturias) in 1952 (picture taken by José Ramón Lueje, reproduced in Lombardía and López. 2003: 203). Different herding strategies involving seasonal mobility were adopted and remained present in these mountains until few decades ago, with shepherds coming from different areas, including nearby mountain valleys from the northern and southern slopes, the Asturian coastal areas around 40-60 km away (the vaqueiros d'alzada), the plains in the South of León province around 60-80 km away, and more distant areas such as the wooden pastures in Salamanca and Extremadura, more than $300 \mathrm{~km}$ away.

\section{Cultural biographies of upland landscapes in the Cantabrian Mountains during Later Prehistory}

\subsection{The Neolithic}

In the area under study, anthropogenic impact on the environment became an increasingly significant agent in the making of upland landscapes during the Neolithic. 
The spread of agricultural and herding activities produced the earliest persistent anthropization of landscapes around 6000 years ago (e.g. López-Merino et al., 2010; Martínez-Cortizas et al., 2009). Neolithic communities developed new subsistence strategies and settlement patterns based on extensive agriculture and herding activities (Cubas-Morera et al., 2016; González-Morales, 2012; Prieto-Martínez et al., 2012). Some recently excavated Neolithic sites north of the Cantabrian Mountains, such as Las Corvas in Vigaña (Balmonte de Miranda, Asturias) (González-Álvarez, 2016: 136-147) and La Torca'l Arroyu (Llanera, Asturias) (Jordá-Pardo et al., 2008), can be interpreted as itinerant sites occupied over periods of a few years and then abandoned. These settlements would have been inhabited in several agrarian seasons, until the soils around them were exhausted by their extensive agricultural strategies. Some of these sites' locations became rather like 'hot spots' for recurrent occupations every few years or decades, as they constituted suitable places for Neolithic livelihoods. However, there is still a significant void in our archaeological knowledge of Neolithic settlement patterns in the study area, particularly of mountainous landscapes. This situation can be related to the lack of previous research in addition to the failure of heritage management policies in Asturias and León, and to the poor design of commercial-led archaeological activities parallel to the construction of infrastructures and urban development. Such archaeological activities have tended to favour well-defined monuments and already known-sites rather than pay attention to the gaps in the archaeological distribution of sites from Later Prehistory (González-Álvarez, 2010).

Novel Neolithic livelihoods resulted in transformations in the vegetation cover, soil composition and geomorphology that can be observed through paleo-environmental and pedological studies (Dincauze, 2000; López-Sáez et al., 2013). The agrarian labour invested by those early farmers was the main agent in the shaping of Later Prehistoric landscapes: woodlands were cleared into open areas for establishing new crops to grow cereals, and pastures to feed domestic herds. This process is reflected by soil composition data gathered in Neolithic agrarian layers documented in the area of La Sienra in Vigaña (Fernández-Mier et al., 2014: 45-47; González-Álvarez, 2016: 131-136). Megaliths constitute another expression of the symbolic and cultural anthropization of upland landscapes beginning in the study area in the Neolithic (AriasCabal et al., 2000). The construction of megaliths and burial mounds may reflect the monumentalizing of domesticated territories through a material manipulation of landscape biographies, reinforcing links between certain human groups and specific territories (Scarre 2002). These monuments would set up a coherent landscape grammar connected with the cosmologies of Neolithic communities (Criado-Boado and MañanaBorrazás 2003; Criado-Boado and Villoch-Vázquez, 2000). Thus, megalithic burial mounds are sometimes related to the best quality summer pastures in these mountains, usually built at locations with high visibility over the surrounding grazing areas, such as La Chalga in Vigaña (Fig. 3). Also, they can mark traditional paths connecting the lowlands and the uplands, in addition to natural fords or mountain passes between nearby valleys, as is illustrated by such examples as the Carondio Mountains (Ayande/Eilao/ Villayón, Asturias) (Graña, 1983). The most suitable spaces to set up summer farms constitute valuable loci for recognizing megaliths, given the locational correlation 
observed between seasonal shepherds' sites from different chronologies and megalithic monuments. Megaliths, both as monuments where ancestors were buried, and as spatial markers built through the cooperative efforts of Neolithic groups, would add to the labour invested by Later Prehistoric upland communities as they cleared the forests and moorlands to create grazing areas for their domestic herds and flocks.

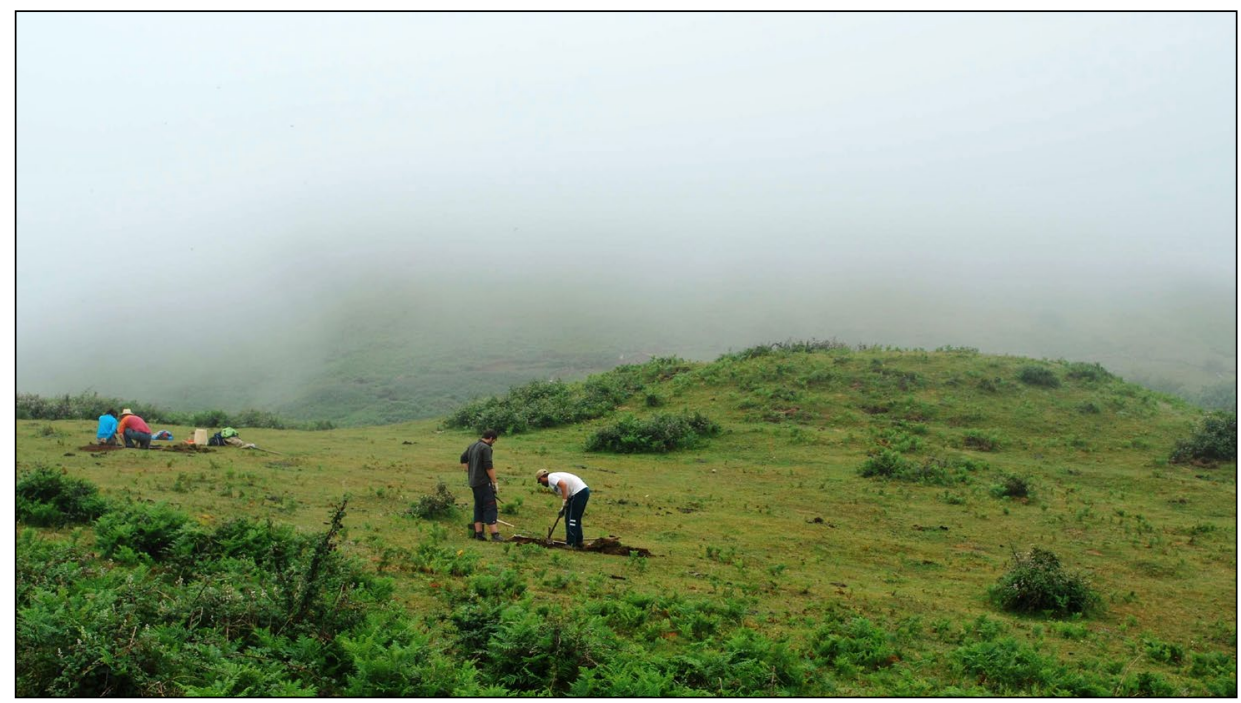

Figure 3. The La Chalga megalithic burial mound in L'Estoupiellu commonlands, near Vigaña (Balmonte de Miranda, Asturias) during the archeological exploration of its surroundings (González-Álvarez et al., 2016).

The expansion of agrarian practices across north-western Iberia is observed earlier in coastal areas (Peña-Chocarro et al., 2005) than in the uplands (Díez-Castillo, 19961997; González-Álvarez, 2018; López-Sáez et al., 2006). Therefore, paleo-environmental datasets in natural deposits near the coast -such as Monte Areo mire (Xixón/Carreño, Asturias) (López-Merino et al., 2010)- reveal the start of anthropogenic pressure on the environment at the beginning of the $5^{\text {th }}$ millennium cal $\mathrm{BC}$, in close relation with an interesting megalithic area (de Blas, 1999). However, investigations carried out in La Molina mire (Salas, Asturias) at $650 \mathrm{~m}$ a.s.l. (López-Merino et al., 2011) or lake Enol (Cangues d'Onís, Asturias) at $1070 \mathrm{~m}$ a.s.l. (Moreno et al., 2011) show later changes in the vegetation cover linked to the anthropization of the uplands, dated around 4000 cal BC. Still, we can observe even more significant chronological variations in the earliest symptoms of landscape anthropization if we pay attention to higher mountain areas (González-Álvarez, 2019). For example, palynological sequences in El Valle lake (Somiedu, Asturias) at $1570 \mathrm{~m}$ a.s.l. (Allen et al., 1996) and a peat bog near Lleitariegos mountain pass (Villablino, León) at $1700 \mathrm{~m}$ a.s.l. (Fombella-Blanco et al. 2003) show no clear anthropogenic pressure until the Iron Age/Roman period. Meanwhile, the nearby palynological datasets of El Castro lake (Villablino, León) at $1317 \mathrm{~m}$ a.s.l. or paleo-lake 
La Mata (Cabrillanes, León) at $1500 \mathrm{~m}$ a.s.l. reveal the presence of herding activities since the 3rd millennium cal BC (Jalut et al., 2010).

Chronological variations in the spread of agriculture and pastoralism through the Cantabrian Mountains may reflect a limited pressure on upland landscapes related to the low demographic density of Neolithic populations. It is also possible that some local groups might have resisted the adoption of agrarian production for a few centuries. Last, we should not disregard the existence of complementary strategies in the exploitation of different altitudinal zones by the same groups, including seasonal herding, hunting and gathering activities in the uplands along with agrarian activities in the lowlands. In any case, the picture depicted by the archaeological and paleo-environmental datasets available lead us to infer that processes in the anthropization of the Cantabrian Mountains during the Neolithic were diversified and regionalized. Future research will have to address such realities in order to develop a more complex social and political understanding of these societies, and to avoid linear and evolutionary interpretations of cultural change throughout Later Prehistory (Parcero-Oubiña and Criado-Boado, 2013).

\subsection{The Bronze Age}

Anthropogenic pressure on the environment increased during the Bronze Age due to the expansion of agricultural, herding and mining activities in the Cantabrian Mountains. Archaeological information for this period is limited in the uplands (de Blas, 1983; Fernández-Manzano, 1996), but it is extensively assumed that subsistence systems and settlement patterns did not change substantially from the Neolithic period (AriasCabal and Armendáriz, 1998; González-Álvarez, 2016).

Paleo-environmental datasets reveal a generalised extension of agricultural and herding activities across the study area, involving a greater diversification in the agrarian landscapes and a more recognisable footprint of the anthropogenic pressure in alpine and subalpine areas (López-Merino, 2009; López-Sáez et al., 2006; Moreno et al., 2011). Palaeoenvironmental sequences in upland natural deposits such as Laguillín lake (Riello, León) at $1850 \mathrm{~m}$ a.s.l. (López-Merino and Manzano-Rodríguez, 2012: 380) and lake Enol (Cangues d'Onís, Asturias) at 1070 $\mathrm{m}$ a.s.1. (Moreno et al., 2011: 344) reflect a significant clearance of forests during the $2^{\text {nd }}$ millennium cal BC that may be related with a growing pastoralist pressure on seasonal grasslands. Moreover, these data inform us about an increase in the anthropogenic pressure which, progressively, reached higher altitudes along the Bronze Age. The gradual clearance of woodlands is reflected differently by the tree species in palynological sequences such as La Mata paleo-lake (Jalut et al., 2010: 344): Quercus started to reduce their distribution first, while Pinus declined later (since $2550 \mathrm{cal} \mathrm{BC}$ ), in a similar process to that suggested by the paleo-environmental data gathered at lake Laguillín. This evolution could be related to a progressive ascent of the anthropization process to the upland areas in the Cantabrian Mountains. Detailed archaeological data is insufficient for a discussion of the meaning of this process in the study area, but traditional discussions about the secondary products exploitation in herding activities (Sherratt 1983) should be considered in connection 
with archaeological data from other European mountainous areas (Barker, 1999; Carrer, 2013a; Ruiz-Gálvez, 1998).

One of the novelties for this period is the development of metallurgy, which prompted an evolution in agrarian technologies and increased the transformative capacity of Bronze Age communities in relation to anthropization processes. Copper ores began to be exploited at the end of the $3^{\text {rd }}$ millennium cal BC, so mining activities must have become another seasonal activity for Bronze Age groups in the uplands (de Blas and Suárez-Fernández, 2010). Some of the most important copper mining complexes in South-Western Europe are located in the Cantabrian Mountains, such as L'Aramo (Llena/Riosa, Asturias), El Milagro (Onís, Asturias) or La Profunda (Cármenes/Villamanín, León). More interestingly, an increase in the anthropogenic pressure on the environment can be perceived in the surroundings of some of these mines. Thus, relevant clearances of forests and moorlands can be observed in L'Aramo massif, as well as symbolic transformations of upland landscapes through the monumentalizing of nodal points in these mountains, which are comparable to those found in Bronze Age megalithic sites such as Los Fitos (Llena/Quirós, Asturias) and La Mata'l Casare (Llena, Asturias) (de Blas, 2012). Indeed, the scale of metallurgy across the region can be assessed in peatlands such as the La Molina peat bog (Salas, Asturias) (Martínez-Cortizas et al., 2016), where the study of atmospheric metal pollution indicators in the long-term sedimentological sequence shows the growing impact of metallurgical activities during the Bronze Age.

Again, lack of archaeological information related to settlements emerges as a limit to better assessments of social and cultural contexts for Bronze Age anthropization in the Cantabrian Mountains. Bronze objects and metal hoards are the most eloquent archaeological traces for detecting the presence of communities in the landscape, although clear information about the original contexts where most of these materials were found in the uplands is lacking (de Blas, 1983; Fernández-Manzano, 1996). Interestingly, some Bronze Age artefacts have been found near mountain passes connecting the Northern and Southern slopes in the watershed divide of the Cantabrian Mountains, such as the Las Verdes sickles (Cabrillanes, León), the Palmela point of Peña Ubiña (Llenena, Asturias) or the daggers/short swords from Puerto Gumial (Ayer, Asturias) (Fig. 4). These elements reveal the presence of shepherds, traders and hunters in the uplands during this period, and they could be interpreted as votive deposits related to places of encounter. However, Bronze Age settlements in upland environs are still elusive for archaeologists, with an extremely limited number of examples available. For instance, some charcoal layers found in El Mayéu de Busián (Llena, Asturias) (Camino-Mayor and Estrada-García, 2012) have been related to nearby Bronze Age seasonal sites of this area at $1500 \mathrm{~m}$ a.s.l. Moreover, recent research carried out at summer pastures in Babia (León) is showing the potential of upland archaeology to fill this void in our archaeological knowledge. In 2018, the excavation of an exploratory trench in a ruined dry-stone shelter at $1710 \mathrm{~m}$ a.s.l. near lake Las Verdes in Torre de Babia (Cabrillanes, León) resulted in the identification of Early Bronze Age pottery similar to the materials found in Los Barrios de Luna castle (Celis, 2000-2001). This recently discovered site could be a good example for Bronze Age seasonal exploitation of alpine and subalpine pastures during this period (Fig. 5). 


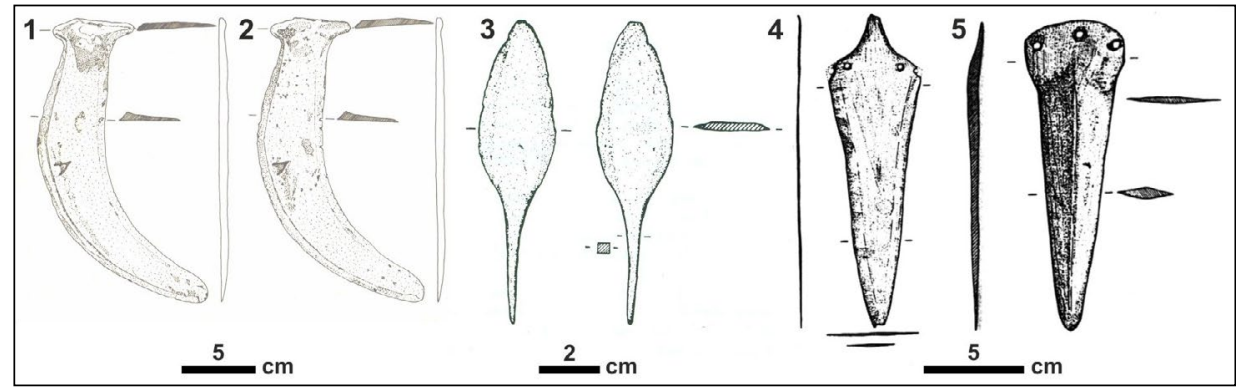

Figure 4. Examples of Bronze Age objects found in mountain passes through the Cantabrian Mountains watershed divide. 1-2: Sickles from Las Verdes (Cabrillanes, León) (in GutierrrezGonzález, 1985: 38). 3: Palmela point of Peña Ubiña (Llena, Asturias) (in de Blas, 1991-1992: 111). 4-5: Daggers/short swords from Puerto Gumial (Ayer, Asturias) (in Marín-Suárez, 2011: 97).

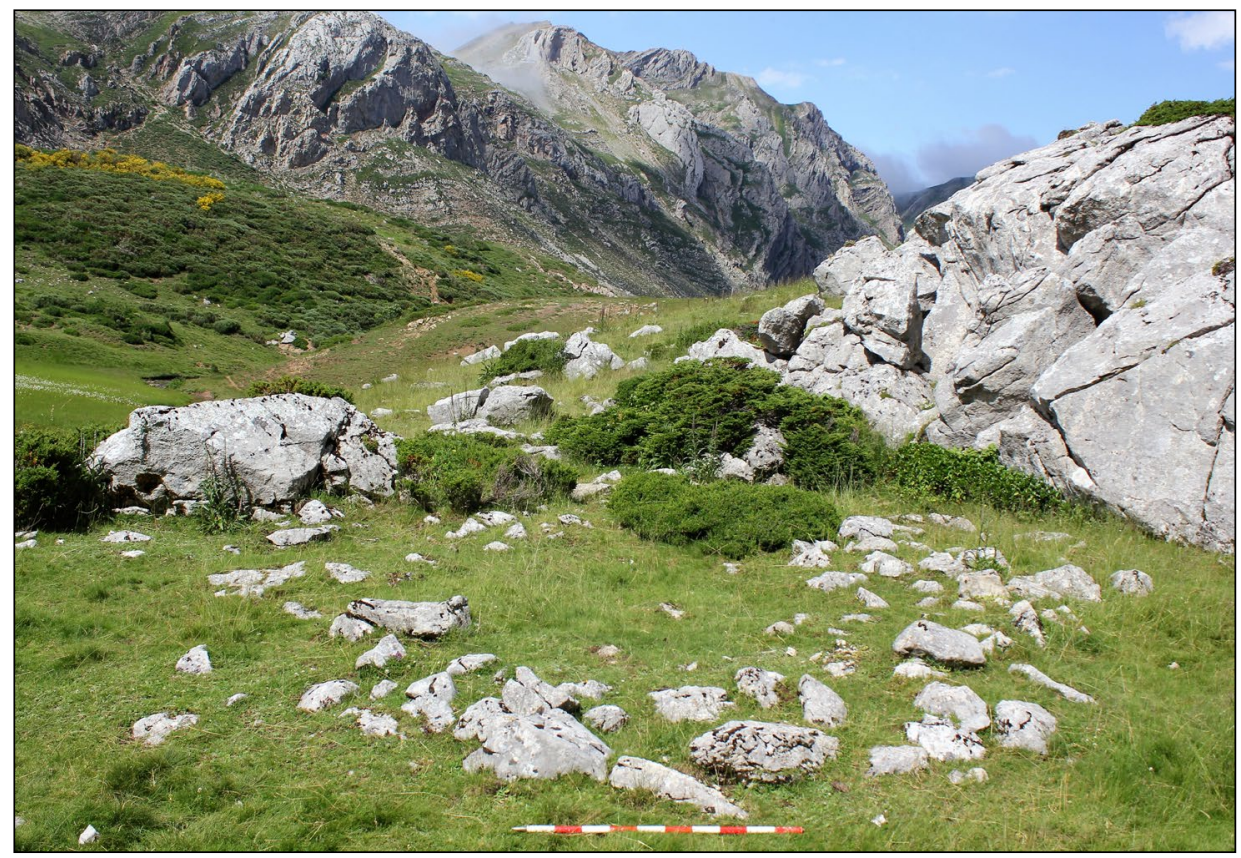

Figure 5. Dry stone structure over 1710 m a.s.l. nearby Las Verdes lake in Torre de Babia (Cabrillanes, León).

The social and symbolic construction of upland landscapes during the Bronze Age can be explored in the light of the spatial distribution of burial mounds and megalithic structures (Arias-Cabal et al., 2006; de Blas, 2012), sites with schematic rock art (Alves and Comendador, 2017; de Blas, 2003), and metallic hoards (Marín-Suárez, 2011a; Ruiz- 
Gálvez, 1998). Some of these elements are linked to natural monuments, mountain passes or natural routes across the mountains which tell us about the relevance of mobility and areas for encounters in the social life of upland Bronze Age communities. As reflected by the scarce archaeological information provided by seasonal sites and isolated metallic findings, the Cantabrian Mountains served as seasonal areas for exploiting several resources that became key in this period's social and natural reproduction of human groups. Far from creating or imposing cultural barriers, uplands became areas for cultural encounters, enhancing contacts and interactions between the groups living North and South of this mountain chain (Marín-Suárez, 2011b).

\subsection{The Iron Age}

At the beginning of the $1^{\text {st }}$ millennium BC, Iron Age communities in the Western Cantabrian Mountains adopted sedentary settlement patterns. These peoples inhabited defensive villages -the castros (hillforts)- built in elevated and highly visible places with impressive defensive structures, including deep ditches, and huge stone walls around these sites (González-Ruibal 2008; Marín-Suárez 2011a) (Fig. 6). Defensive concerns were clearly pressing for these communities, but these architectural devices were also intended to monumentalise their villages. The castros also became nodal points in the construction of Iron Age cultural and productive landscapes, establishing a centralised spatial grammar that materialised the tight and centripetal relation between communities and their surrounding environs.

Novel agrarian techniques allowed Iron Age groups to establish permanent agricultural fields around the hillforts thanks to new iron tools, manuring the soil, and the diversification of cultivated species of cereals and legumes (Parcero-Oubiña et al., 2007). Some archaeological examples from North-Western Iberia show the Iron Age creation of stable agrarian plots that might have sustained sedentarism and diversification of productive landscapes around the hillforts (López-Sáez et al., 2009; Parcero-Oubiña, 2006). However, due to the underdevelopment of landscape archaeology in this region, we have little information about these structures in the Cantabrian Mountains, such as the only example of a drainage structure found by a commercial-led project in Villanueva de Santu Adrianu (Asturias) (Montes-López, 2015: 107-110).

The cultivation of new cereal species such as millet would have allowed Iron Age groups to grow two harvests a year, reducing uncertainty and enabling agrarian surplus. As a result, a demographic expansion can be recorded during the whole period, with more and bigger hillforts being built as the Iron Age advanced (Marín-Suárez, 2011a), and a growing complexity in the social organization of these communities (GonzálezRuibal, 2012). New herding strategies specialised in cattle were also developed, with seasonal alpine mobility taking advantage of the grasslands in upland areas during summer (González-Álvarez, 2011). The expansion of iron and bronze metallurgy (Fanjul-Peraza and Marín-Suárez, 2006; Farci et al., 2017) contributed to the generation of greater anthropogenic impacts on the environment, due to the increasing needs of charcoal as fuel, that might have contributed to increased deforestation (Kaal et al., 2011). For instance, recent research has identified some structures dated at the end of 
the $1^{\text {st }}$ millennium cal BC related to charcoal production in Almoñu (Ayande, Asturias) (Menéndez-Blanco et al., 2018), near the hillfort of San Chuis in Samartín de Beduledo (Ayande, Asturias). Iron metallurgy was a relevant activity for the Iron Age inhabitants of this site (Jordá-Pardo et al., 2011), demanding charcoal as fuel for the metal production, as anthracological studies have shown (Badal-García et al., 2012).

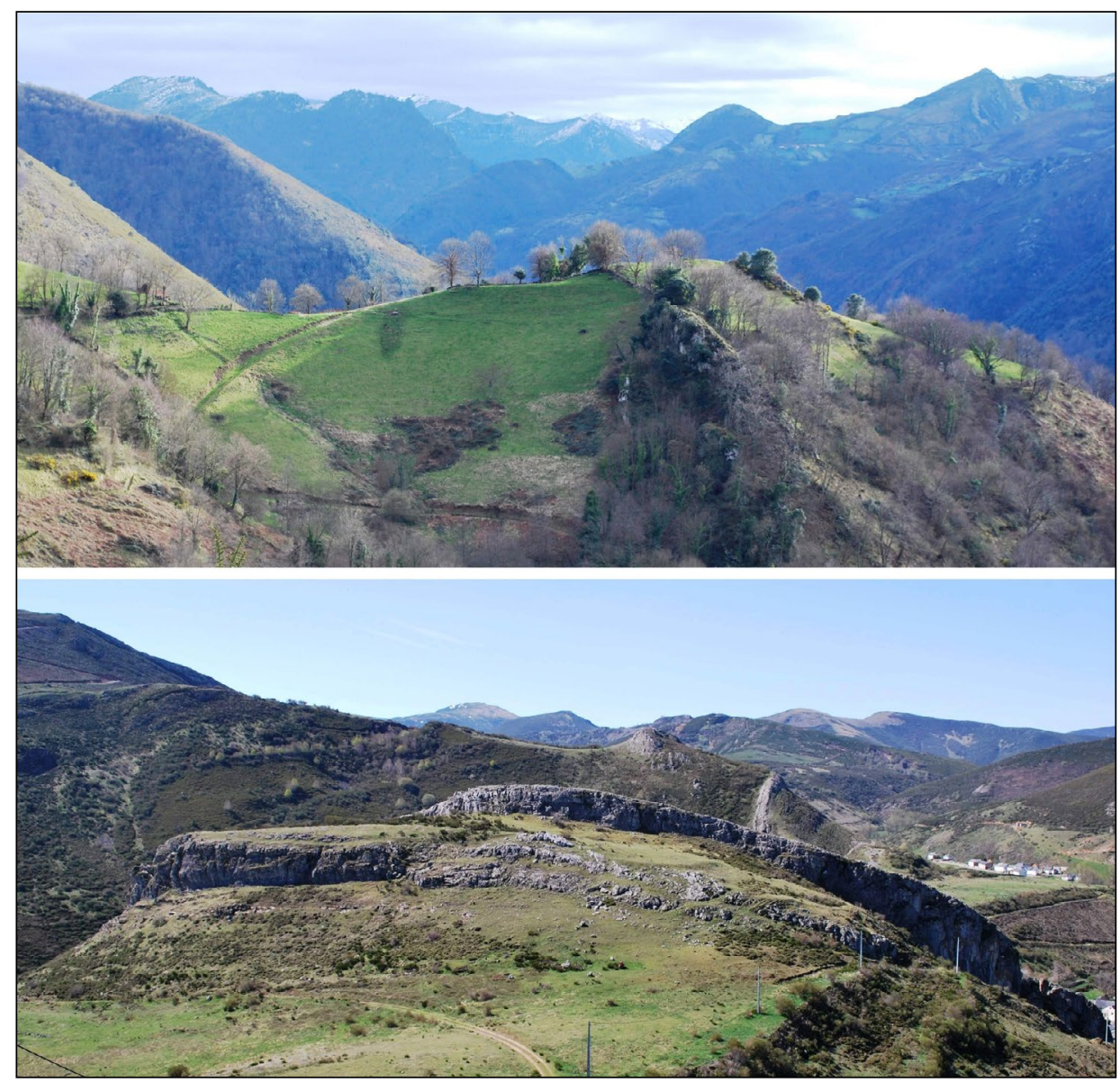

Figure 6. Iron Age hillforts of El Monte la Caimada, near Tiblós (Balmonte de Miranda, Asturias) at 562 m a.s.l. (above) and El Pico Sulcastro, in Quintanilla de Babia (Cabrillanes, León) at 1375 m a.s.l. (below).

As demonstrated by recent interdisciplinary investigations of sites such as El Castru in Vigaña (Balmonte de Miranda, Asturias), the extension of agricultural and herding activities, and the new settlement patterns around permanent villages had a clear impact on the study area's environment (González-Álvarez et al., 2018). However, regional variations have to be assumed within north-western Iberia regarding social, political and 
also productive landscapes (González-Ruibal, 2012). For this reason, we must emphasize the agency of Iron Age communities, where regionalised cultural traits would mediate the ways in which these groups would have interacted with the surrounding landscapes. This way, the cultural development of Iron Age societies should be considered at the same level as adaptation to the environment as the basis to understand the social construction of Iron Age cultural landscapes, even in such extreme environs as the upland areas which are the focus of this paper.

Paleo-environmental datasets from the $1^{\text {st }}$ millennium BC show an increase in the relevance of open areas and a growing diversification of agrarian landscapes in some of the already mentioned paleo-environmental datasets of the Cantabrian Mountains. Open areas and crops widen their extension, even according to the higher paleo-environmental datasets from lake El Valle (López-Merino, 2009) or lake El Castro (Jalut et al., 2010), where cereals appeared at the end of the Iron Age. Changes in the production strategies deployed by pre-Roman communities created compartmentalized agrarian landscapes around the hillforts where anthropogenic pressure increased in a nuclearized manner (González-Álvarez, 2016). As monumentalized and well-defended villages, hillforts became the central nodes in Iron Age cultural, political and productive landscapes. Some authors have characterised these landscapes as 'divided' in relation to the increasing territorialisation of productive and political landscapes during the Iron Age (ParceroOubiña et al., 2007; Parcero-Oubiña and Criado-Boado, 2013) and the growing discursive relevance of warfare for these societies (González-García, 2009).

These models endured until the expansion of the Roman state to north-western Iberia 2000 years ago in the so-called 'Cantabrian Wars' (29-19 BC) (Costa-García, 2018). During these military campaigns, the Cantabrian Mountains became one of the most relevant areas. Indeed, two dozens of Roman military camps have been identified in the study area's uplands, showing the most likely paths followed by the Roman troops (Camino-Mayor et al., 2015; Costa-García et al., 2018). These archaeological footprints emphasize the relevance that mountains played in communications and political landscapes between the late Iron Age and the early Roman period. After a short transitional period, most of the hillforts were abandoned and new social and productive landscapes shaped during the Roman period by the foundation of open villages near old castros, and the integration of indigenous communities into the Roman state (MarínSuárez and González-Álvarez, 2011; Sastre, 2001).

\section{Final remarks}

The integrated analysis of archaeological and paleo-environmental datasets emphasizes the need to develop interdisciplinary investigations to unravel the long-term biographies of cultural landscapes. Landscape Archaeology is a fruitful theoretical and methodological research strategy that reveals the anthropogenic impact in alpine and subalpine areas of the Cantabrian Mountains since Later Prehistory. The anthropization of upland landscapes was closely connected with the social, cultural and productive traits of the societies who inhabited the study area over different chronologies. However, evolutionary readings of ancient landscapes that mainly rely 
on paleo-environmental datasets tend to oversimplify in their explanations of landscape biographies. Therefore, we need to fill the voids in our archaeological knowledge of the human exploitation of upland environs in the Cantabrian Mountains. This way, we will be able to build richer narratives about the anthropization of the study area along Later Prehistory, emphasizing human agency in the shaping of landscapes and paying attention to the cultural particularities adopted by local communities during different periods.

Current debates around the Anthropocene constitute an outstanding opportunity for landscape archaeology to enhance interdisciplinary discussions. This approach may help us raise new research questions that address thicker and more complex interpretations about the interaction between societies and their surrounding environments. In addition, these investigations will reinforce the relevance of archaeology in wider disciplinary contexts within social sciences and humanities. Archaeological investigations on the long-term evolution of prehistoric landscapes might help us to go beyond paleoenvironmental or geomorphological readings that currently sustain the more extended views on the Anthropocene. In particular, discussions around the Anthropocene focusing on the last few centuries tend to oversimplify the ways in which human beings have interacted with the environment in the framework of industrial societies and capitalism. Looking back to more distant periods can help us reflecting on the relevance of social, political and cultural mediations in the anthropogenic making of cultural landscapes.

\section{References}

Abarquero, F.J., Delibes-de Castro, G., Fernández-Rodríguez, C., González-Fernández, M.L., López-Sáez, J.A. 2009. Una ojeada a la hipótesis de la hipermovilidad de los pastores de excisión y boquique a la luz de los documentos de El Pelambre. In: M.L. González-Fernández (Ed.), El Pelambre, Villaornate, León. El Horizonte Cogotas I de la Edad del Bronce y el período tardoantiguo en el valle medio del Esla. Tragsa, Oviedo, pp. 291-301.

Allen, J.R.M., Huntley, B., Watts, W.A. 1996. The vegetation and climate of northwest Iberia over the last 14,000 years. Journal of Quaternary Science 11 (2), 125-147. https://doi.org/10.1002/ (SICI)1099-1417(199603/04)11:2<125::AID-JQS232>3.0.CO;2-U.

Alves, L.B., Comendador, B. 2017. Arte esquemático pintado en el noroeste peninsular: una visión integrada transfronteriza. Gallaecia 36, 11-52.

Anschuetz, K.F., Wilshusen, R.H., Scheick, C.L. 2001. An Archaeology of Landscapes: Perspectives and Directions. Journal of Archaeological Research 9 (2), 157-211. https://doi. org/10.1023/A:101661326415.

Argüello-Menéndez, J.J. 2008. Minería y Metalurgia en la Asturias Medieval. Vessants, Palma.

Arias-Cabal, P., Altuna, J., Armendáriz, A., González-Urquijo, J.E., Ibáñez-Estévez, J.J., Ontañón, R., Zapata-Peña, L. 2000. La transición al Neolítico en la Región Cantábrica. Estado de la Cuestión. In: P. Arias-Cabal, P. Bueno-Ramírez, D. Cruz, J.X. Enríquez, J. Oliveira, M.J. Sanches (Eds.), Actas do $3^{\circ}$ Congresso de Arqueologia Peninsular, vol. 3: Neolitizaçao e Megalitismo da Peninsula Ibérica. ADECAP, Porto, pp. 115-131.

Arias-Cabal,P., Armendáriz, A. 1998. Aproximación a la Edad del Bronce en la Región Cantábrica. In: R. Fábregas (Ed.), A Idade do Bronce en Galicia: Novas Perspectivas. Ediciós do Castro, A Coruña, pp. 47-80. 
Arias-Cabal,P., Armendáriz, A., Teira-Mayolini,L.C. 2006. The Megalithic complex in Cantabrian Spain. In: A.A. Rodríguez-Casal (Ed.), Le Mégalithisme Atlantique. Archaeopress (BAR International Series; 1521), Oxford, pp. 11-29.

Armstrong, C.G., Shoemaker, A.C., McKechnie, I., Ekblom, A., Szabó, P., Lane, P.J., McAlvay, A.C., Boles, O.J., Walshaw, S., Petek, N., Gibbons, K.S., Quintana Morales, E., Anderson, E.N., Ibragimow, A., Podruczny, G., Vamosi, J.C., Marks-Block, T., LeCompte, J.K., Awâsis, S., Nabess, C., Sinclair, P., Crumley, C.L. 2017. Anthropological contributions to historical ecology: 50 questions, infinite prospects. PLOS ONE 12 (2), e0171883. https://doi. org/10.1371/S0068246200004517.

Badal-García, E., Carrión-Marco, Y., Jordá-Pardo, J.F. 2012. Charcoal analysis at the San Chuis hill fort (Allande, Asturias, Spain). In: E. Badal-García, Y. Carrión-Marco, M. Macías, M. Ntinou (Eds.), Wood and Charcoal Evidence for Human and Natural History. Universitat de Valencia (Sagvntvm Extra; 13), Valencia, pp. 125-134.

Barker, G. 1999. Hunting and Farming in Prehistoric Italy: Changing Perspectives on Landscape and Society. Papers of the British School at Rome 67, 1-36. https://doi.org/10.1017/ S0068246200004517.

Bender, B. (Ed.) 1993. Landscape: Politics and Perspectives. Berg, Oxford.

Braje, T.J. 2015. Earth Systems, Human Agency, and the Anthropocene: Planet Earth in the Human Age. Journal of Archaeological Research 23 (4), 369-396. https://doi.org/10.1007/ s10814-015-9087-y.

Camino-Mayor, J., Estrada-García, R. 2012. El mayéu Busián (Lḷena): orixe d’una braña na Edá del Bronce. Asturies: memoria encesa d'un país 32, 4-11.

Camino-Mayor, J., Peralta-Labrador, E., Torres-Martínez, J.F. (Eds.) 2015. Las Guerras ÁsturCántabras. KRK Ediciones, Gijón.

Carrer, F. 2013a. Archeologia della pastorizia nelle Alpi: nuovi dati e vecchi dubbi. Preistoria Alpina 47, 49-56.

Carrer, F. 2013b. An ethnoarchaeological inductive model for predicting archaeological site location: A case-study of pastoral settlement patterns in the Val di Fiemme and Val di Sole (Trentino, Italian Alps). Journal of Anthropological Archaeology 32 (1), 54-62. https://doi. org/10.1016/j.jaa.2012.10.001.

Carrington, D. 2016. The Anthropocene epoch: scientists declare dawn of human-Influenced age, The Guardian 29/08/2016. https://www.theguardian.com/environment/2016/aug/29/declareanthropocene-epoch-experts-urge-geological-congress-human-impact-earth (last access: $14 / 08 / 2018)$.

Celis, J. 1996. Origen, desarrollo y cambio en la Edad de Hierro de las tieras leonesas. In: ArqueoLeón. Historia de León a través de la arqueología. Junta de Castilla y León; Diputación Provincial de León, León, pp. 41-67.

Celis, J. 2000-2001. El castillo de los Barrios de Luna. Un yacimiento del Bronce Inicial-Medio en el occidente de la cordillera cantábrica. Lancia 4, 85-102.

Costa-García, J.M. 2018. Rediscovering the Roman Conquest of the North-Western Iberian Peninsula. In: Fernández-Götz, M.A., Roymans, N. (Eds.), Conflict Archaeology: Materialities of Collective Violence from Prehistory to Late Antiquity. Routledge, European Association of Archaeologists (Themes in Contemporary Archaeology; 5), London, pp. 141151.

Costa-García, J.M., Menéndez-Blanco, A., González-Álvarez, D., Gago-Mariño, M., Fonte, J., Blanco-Rotea, R., Álvarez-Martínez, V. 2018. The Presence of the Roman Army in NorthWestern Hispania: New Archaeological Data from Ancient Asturias and Galicia. In: C.S. Sommer, S. Matešić, S. (Eds.), Limes XXIII. Proceedings of the 23rd International Limes Congress in Ingolstadt 2015, Volume II. Nünnerich-Asmus Verlag, Mainz, pp. 903-910. 
Costello, E., Svensson, E. (Eds.) 2018. Historical Archaeologies of Transhumance across Europe. Routledge; European Association of Archaeologists (Themes in Contemporary Archaeology; 6), London. https://doi.org/10.4324/9781351213394.

Criado-Boado, F. 1993. Límites y posibilidades de la arqueología del paisaje. SPAL 2, 9-55. https:// doi.org/10.12795/spal.1993.i2.01.

Criado-Boado, F. 1999. Del terreno al espacio: planteamientos y perspectivas para la Arqueología del Paisaje. Grupo de Investigación en Arqueología del Paisaje, Universidade de Santiago de Compostela (CAPA; 6), Santiago de Compostela.

Criado-Boado, F., Mañana-Borrazás, P. 2003. Arquitectura como materialización de un concepto. La espacialidad megalítica. Arqueología de la Arquitectura 2, 103-111. https://doi. org/10.3989/arq.arqt.2003.31.

Criado-Boado, F., Villoch-Vázquez, V. 2000. Monumentalizing landscape: from present perception to the past meaning of Galician megalithism (north-west Iberian Peninsula). European Journal of Archaeology 3 (2), 188-216. https://doi.org/10.1179/eja.2000.3.2.188.

Crumley, C.L. 1994. Historical Ecology: A Multidimensional Ecological Orientation. In: C.L. Crumley (Ed.), Historical Ecology: Cultural knowledge and changing landscapes. School of American Research Press, Santa Fe, 1-16.

Crutzen, P.J. 2002. Geology of mankind. Nature 415, 23. https://doi.org/10.1038/415023a.

Crutzen, P.J. 2006. The “Anthropocene”. In: E. Ehlers, T. Krafft (Eds.), Earth System Science in the Anthropocene. Springer, Berlin, 13-18. https://doi.org/10.1007/3-540-26590-2_3.

Crutzen, P.J., Stoermer, E. 2000. The Anthropocene. Global Change Newsletter 41 (1), 17-18.

Cubas-Morera, M., Altuna, J., Álvarez-Fernández, E., Armendáriz, A., Fano-Martínez, M.A., López-Dóriga, I.L., Mariezkurrena, K., Tapia, J., Teira-Mayolini, L.C., Arias-Cabal, P. 2016. Re-evaluating the Neolithic: The Impact and the Consolidation of Farming Practices in the Cantabrian Region (Northern Spain). Journal of World Prehistory 29 (1), 79-116. https://doi. org/10.1007/s10963-016-9091-2.

David, B., Thomas, J. (Eds.) 2008. Handbook of Landscape Archaeology. Left Coast Press, Walnut Creek.

de Blas, M.A. 1983. La Prehistoria Reciente en Asturias. Fundación Pública de Cuevas y Yacimientos Prehistóricos de Asturias, Oviedo.

de Blas, M.A. 1991-1992. Nuevos testimonios metalúrgicos de la Edad del Bronce en el centrooccidente de la región cantábrica. Veleia 8-9, 109-137.

de Blas, M.A. 1999. El Monte Areo, en Carreño (Asturias): un territorio funerario de los milenios $V$ a III a. de J.C. Ayuntamiento de Carreño; Mancomunidad Cabo Peñas, Candás.

de Blas, M.A. 2012. Beneficio y consagración de las cumbres: el caso de Los Fitos y la concurrencia Neolítico-Bronce antiguo en el área megalítica de La Cobertoria, Asturias. In: J.R. Muñiz (Ed.), Ad Orientem. Del final del Paleolítico en el norte de España a las primeras civilizaciones del Oriente Próximo. Estudios en homenaje a Juan Antonio FernándezTresguerres Velasco. Universidad de Oviedo; Ménsula ediciones, Oviedo, pp. 307-347.

de Blas, M.A. 2003. Estelas con armas: arte rupestre y paleometalurgia en el norte de la Península Ibérica. In: R. Balbín-Behrmann, P. Bueno-Ramírez (Eds.), El arte prehistórico desde los inicios del siglo XXI. Primer Symposium Internacional de Arte Prehistórico de Ribadesella. Ribadesella: Amigos de Ribadesella, Cajastur, Ministerio de Ciencia y Tecnología, Real Instituto de Estudios Asturianos, pp. 391-417.

de Blas, M.A. 2012. Beneficio y consagración de las cumbres: el caso de Los Fitos y la concurrencia Neolítico-Bronce antiguo en el área megalítica de La Cobertoria, Asturias. In: J.R. Muñiz (Ed.), Ad Orientem. Del final del Paleolítico en el norte de España a las primeras civilizaciones del Oriente Próximo. Estudios en homenaje a Juan Antonio FernándezTresguerres Velasco. Universidad de Oviedo; Ménsula ediciones, Oviedo, pp. 307-347. 
de Blas, M.A., Fernández-Tresguerres, J. 1989. Historia primitiva en Asturias. De los cazadoresrecolectores a los primeros metalúrgicos. Silverio Cañada, Gijón.

de Blas, M.A., Suárez-Fernández, M. 2010. La minería subterránea del cobre en Asturias: un capítulo esencial en la Prehistoria reciente del norte de España. In: J. Fernández-Tresguerres (Ed.), Cobre y Oro. Minería y metalurgia en la Asturias prehistórica y antigua. Real Instituto de Estudios Asturianos, Oviedo, pp. 43-82.

Delibes-de Castro, G., Fernández-Manzano, J. 1983-1984. Bronce Final atlántico en el Noroeste de la cuenca del Duero. Portugalia 4-5, 111-119.

Descola, P. 2005. Par-delà nature et culture. Éditions Gallimard, Paris.

Díez-Castillo, A. 1996-1997. Utilización de los recursos en la Marina y Montaña cantábricas: una prehistoria ecológica de los valles del Deva y Nansa. Asociación Cultural de Arqueología AGIRI (Illunzar; 96-97), Gernika.

Dincauze, D.F. 2000. Environmental Archaeology. Principles and Practice. Cambridge University Press, Cambridge. https://doi.org/10.1017/CBO9780511607837.

Edgeworth, M., Richter, D., Waters, C., Haff, P., Neal, C., Price, S.J. 2015. Diachronous beginnings of the Anthropocene: The lower bounding surface of anthropogenic deposits. The Anthropocene Review 2 (1), 33-58. https://doi.org/10.1177/2053019614565394.

Fanjul-Peraza, A., Marín-Suárez, C. 2006. La metalurgia del hierro en la Asturias castreña: nuevos datos y estado de la cuestión. Trabajos de Prehistoria 63 (1), 113-131.

Fano-Martínez, M.A., Cubas-Morera, M., Wood, R. 2015. The first farmers in Cantabrian Spain: Contribution of numerical chronology to understand an historical process. Quaternary International 364, 153-161. https://doi.org/10.1016/j.quaint.2014.09.026.

Farci, C., Martinón-Torres, M., González-Álvarez, D. 2017. Bronze production in the Iron Age of the Iberian Peninsula: The case of El Castru, Vigaña (Asturias, NW Spain). Journal of Archaeological Science: Reports 11,338-351. https://doi.org/10.1016/jasrep.2016.12.009.

Fernández-Durán, R. 2011. El Antropoceno: la expansión del capitalismo global choca con la biosfera. Virus, Barcelona.

Fernández-Manzano, J. 1996. Calcolítico y Edad del Bronce en la provincia de León. In: ArqueoLeón. Historia de León a través de la arqueología. Junta de Castilla y León, Diputación Provincial de León, León, pp. 29-40.

Fernández-Mier, M., Fernández-Fernández, J., Alonso-González, P., López-Sáez, J.A., PérezDíaz, S., Hernández-Beloqui, B. 2014. The investigation of currently inhabited villages of medieval origin: Agrarian archaeology in Asturias (Spain). Quaternary International 346, 41-55. https://doi.org/10.1016/j.quaint.2014.01.032.

Fernández-Mier, M., López-Gómez, P., González-Álvarez, D. 2013. Prácticas ganaderas en la Cordillera Cantábrica. Aproximación multidisciplinar al estudio de las áreas de pasto en la Edad Media. Debates de Arqueología Medieval 3, 167-219.

Finney, S.C. 2016. The "Anthropocene" epoch: Scientific decision or political statement?. Gsa Today 26 (3-4), 4-10. https://doi.org/10.1130/GSATG270A.1.

Fombella-Blanco, M.A., García-Rovés, E., Puente-García, E. 2003. Comparative palynological analysis between the San Isidro and Leitariegos Holocene sequences, NW Spain. Acta Palaeontologica Sinica 42 (1), 111-117.

García-Martínez, A. 2003. La trashumancia en Asturias. In: L.V. Elías, F. Novoa (Eds.), Un camino de ida y vuelta. La trashumancia en España. Lunwerg, Barcelona, pp. 95-107.

Garrido-Pena, R., Rojo-Guerra, M.A., García-Martínez de Lagrán, I., Tejedor-Rodríguez, C. 2012. Cuenca del Duero. In: M.A. Rojo-Guerra, R. Garrido-Pena, I. García-Martínez de Lagrán (Eds.), El Neolítico en la Península Ibérica y su contexto europeo. Cátedra, Madrid, pp.463-505.

Gassiot-Ballbè, E., Rodríguez-Antón, D., Pèlachs-Mañosa, A., Pérez-Obiol, R., Julià-Brugués, R., Bal-Serin, M-C., Mazzucco, N. 2014. La alta montaña durante la Prehistoria: 10 años 
de investigación en el Pirineo catalán occidental. Trabajos de Prehistoria 71 (2), 261-281. https://doi.org/10.3989/tp.2014.12134.

González-Álvarez, D. 2010. El Parque Eólico Sierra de Carondio: Una oportunidad perdida para el conocimiento de la Prehistoria reciente cantábrica. Estrat Crític 4, 75-88.

González-Álvarez, D. 2011. Movilidad ganadera entre las comunidades castreñas cantábricas: el valle del Pigüeña (Asturias) como caso de estudio. In: Actas de las II Jornadas de Jóvenes en Investigación Arqueológica (JIA 2009), tomo I. Pórtico, Zaragoza, pp. 147-156.

González-Álvarez, D. 2013. Traditional Pastoralism in the Asturian Mountains: an Ethnoarchaeological View on Mobility and Settlement Patterns. In: F. Lugli, A.A. Stoppiello, S. Biagetti (Eds.), Ethnoarchaeology: Current Research and Field Methods. Conference Proceedings, Rome, Italy, 13 $3^{\text {th }}-14^{\text {th }}$ May 2010. Archaeopress (BAR International Series; 2472), Oxford, pp. 202-208.

González-Álvarez, D. 2016. Poblamiento y antropización de la montaña occidental cantábrica durante la Prehistoria reciente: una aproximación desde la Arqueología del Paisaje. Department of Prehistory, Complutense University of Madrid (Unpublished $\mathrm{PhD}$ dissertation). http://eprints.ucm.es/39363/.

González-Álvarez, D. 2018. La antropización de los espacios montañosos del Occidente Cantábrico: el Neolítico en el valle del río Pigüeña (Asturias). In: Actas del VI Congreso del Neolítico en la Península Ibérica. Universidad de Granada, Granada.

González-Álvarez, D. 2019. Humanizing the Western Cantabrian Mountains in Northwestern Iberia: a diachronic perspective on the exploitation of the uplands during Late Prehistory. In: C. Ray, M. Fernández-Götz (Eds.), Historical Ecology and Complex Societies. Routledge, New York.

González-Álvarez, D., Fernández-Mier, M., López-Gómez, P. 2016. An Archaeological Approach to the brañas: summer farms in the pastures of the Cantabrian Mountains (northern Spain). In: J.R. Collis, M. Pearce, F. Nicolis (Eds.), Summer Farms. Seasonal Exploitation of the Uplands from Prehistory to the Present. Equinox Publishing (Sheffield Archaeological Monographs; 16), Sheffield, pp. 203-219.

González-Álvarez, D., Marín-Suárez, C., Farci, C., López-Gómez, P., López-Sáez, J.A., MartínezBarrio, C., Martinón-Torres, M., Menéndez-Blanco, A., Moreno-García, M., Núñez-de la Fuente, S., Peña-Chocarro, L., Pérez-Jordá, G., Rodríguez-Hernández, J., Tejerizo-García, C., Fernández-Mier, M. (2018). El Castru (Vigaña, Belmonte de Miranda, Asturias): un pequeño poblado fortificado de las montañas occidentales cantábricas durante la Edad del Hierro. Munibe. Antropologia-Arkeologia 69, 211-237. https://doi.org/10.21630/maa.2018.69.14.

González-García, F.J. 2009. Between warriors and champions: warfare and social change in the Later Prehistory of the North-Western Iberian Peninsula. Oxford Journal of Archaeology 28 (1), 59-76. https://doi.org/10.1111/j.1468-0092.2008.00319.x.

González-Morales, M.R. 2012. Cantabria. In: M.A. Rojo-Guerra, R. Garrido-Pena, I. GarcíaMartínez de Lagrán (Eds.), El Neolítico en la Península Ibérica y su contexto europeo. Cátedra, Madrid, pp. 255-290.

González-Ruibal, A. 2003. La experiencia del otro. Una introducción a la Etnoarqueología. Akal, Madrid.

González-Ruibal, A. 2008. Los pueblos del noroeste. In: F. Gracia-Alonso (Ed.), De Iberia a Hispania. Ariel, Madrid, 899-930.

González-Ruibal, A. 2012. The politics of identity: ethnicity and the economy of power in Iron Age northern Iberia. In: G. Cifani, S. Stoddart (Eds.), Landscape, ethnicity and identity in the archaic Mediterranean area. Oxbow Books, Oxford, pp. 245-266.

Graña, A. 1983. El conjunto tumular de «La carreiriega de los gallegos» (Sierra de Carondio, Allande). Ástura, Nuevos cortafueyos d'Asturies 1, 21-34. 
Gutiérrez-González, J.A. 1985. Poblamiento antiguo y medieval de la montaña central leonesa. Institución Fray Bernardino de Sahagún, León.

Haraway, D. 2015. Anthropocene, Capitalocene, Plantationocene, Chthulucene: Making Kin. Environmental Humanities 6 (1), 159-165. https://doi.org/10.1215/22011919-3615934.

Herrán-Martínez, J.I. 2008. Arqueometalurgia de la Edad del Bronce en Castilla y León. Universidad de Valladolid (Studia Archaeologica 95), Valladolid.

Hirsch, E., O'Hanlon, M. (Eds.) 1995. The Anthropology of Landscape. Perspectives on Place and Space. Clarendon Press, Oxford.

Ingersn, A.E. 1994. Tracking and Testing the Nature-Culture Dichotomy. In: C.L. Crumley (Ed.), Historical Ecology: Cultural knowledge and changing landscapes. School of American Research Press, Santa Fe, pp. 43-66.

Ingold, T. 1993. The temporality of the landscape. World Archaeology 25 (2), 152-174. https://doi. org/10.1080/00438243.1993.9980235.

Ingold, T. 2000. The Perception of the Environment. Essays on livelihood, dwelling and skill. Routledge, London.

Jalut, G., Turu i Michels, V., Dedoubat, J-J., Otto, T., Ezquerra, J., Fontugne, M., Belet, J.M., Bonnet, L., García-de Celis, A., Redondo-Vega, J.M., Vidal, J.R., Santos, L. 2010. Palaeoenvironmental studies in NW Iberia (Cantabrian range): Vegetation history and synthetic approach of the last deglaciation phases in the western Mediterranean. Palaeogeography, Palaeoclimatology, Palaeoecology 297 (2), 330-350. https://doi. org/10.1016/j.palaeo.2010.08.012.

Jimeno, A. 2001. El modelo de trashumancia aplicado a la cultura de Cogotas I. In: Ruiz-Gálvez, M. (Ed.), La Edad del Bronce, ¿primera Edad de Oro en España?: Sociedad, economía e ideología. Crítica, Barcelona, pp. 139-180.

Johnson, M.H. 2007. Ideas of Landscape. Blackwell Publishing, Oxford. https://doi. org/10.1002/9780470773680.

Jordá-Pardo, J.F., Estrada-García, R., Mestres-Torres, J.S., Yravedra, J., Marín-Suárez, C. 2008. Un asentamiento neolítico de superficie en el interior de una cueva: Torca l'Arroyu (Llanera, Asturias, España). In: M.S. Hernández, J.A. Soler, J.A. López-Padilla (Eds.), IV Congreso del Neolítico Peninsular, 27-30 de noviembre de 2006, tomo I. MARQ, Diputación Provincial de Alicante, Alicante, pp. 208-215.

Jordá-Pardo, J.F., Marín-Suárez, C., García-Guinea, J. 2011. Discovering San Chuis Hillfort (Northern Spain): Archaeometry, Craft Technologies, and Social Interpretation. In: T. Moore, X.L. Armada-Pita (Eds.), Atlantic Europe in the First Millennium BC. Crossing the Divide. Oxford University Press, Oxford, pp. 488-505.

Kaal, J., Carrión-Marco, Y., Asouti, E., Martín-Seijo, M., Martínez-Cortizas, A., Costa-Casais, M., Criado-Boado, F. 2011. Long-term deforestation in NW Spain: linking the Holocene fire history to vegetation change and human activities. Quaternary Science Reviews 30 (1-2), 161-175. https://doi.org/10.1016/j.quascirev.2010.10.006.

Lane, P.J. 2015. Archaeology in the age of the Anthropocene: A critical assessment of its scope and societal contributions. Journal of Field Archaeology 40 (5), 485-498. https://doi. org/10.1179/2042458215Y.0000000022.

Latour, B. 2013. An inquiry into modes of existence: an anthropology of the moderns. Harvard University Press, Cambridge (MA).

Lewis, S.L., Maslin, M.A. 2015. Defining the Anthropocene. Nature 519, 171. https://doi. org/10.1038/nature14258.

Lombardía, C., López, J. (Eds.) 2003. José Ramón Lueje. La montaña fotografiada (1936-1975). Fundación Municipal de Cultura, Educación y Universidad Popular, Ayuntamiento de Gijón, Gijón. 
López-Merino, L. 2009. Paleoambiente y Antropización en Asturias durante el Holoceno. Department of Ecology, Autonomous University of Madrid (Unpublished PhD dissertation). http://hdl.handle.net/10486/128/.

López-Merino, L., Manzano-Rodríguez, S. 2012. Laguillín. In: J.S. Carrión-García (Dir.), Paleoflora y Paleovegetación de la Península Ibérica e Islas Baleares: Plioceno-Cuaternario. Ministerio de Economía y Competitividad, Madrid, 378-380.

López-Merino, L., Martínez-Cortizas, A., López-Sáez, J.A. 2010. Early agriculture and palaeoenvironmental history in the North of the Iberian Peninsula: a multi-proxy analysis of the Monte Areo mire (Asturias, Spain). Journal of Archaeological Science 37 (8), 1978-1988. https://doi.org/10.1016/j.jas.2010.03.003.

López-Merino, L., Martínez-Cortizas, A., López-Sáez, J.A. 2011. Human-induced changes on wetlands: a study case from NW Iberia. Quaternary Science Reviews 30 (19-20), 2745-2754. https://doi.org/10.1016/j.quascirev.2011.06.004.

López-Sáez, J.A., Iriarte-Chiapusso, M.J., Burjachs, F. 2013. Arqueopalinología. In: GarcíaDíez, M., Zapata-Peña, L. (Eds.), Métodos y Técnicas de análisis y estudio en arqueología prehistórica. De lo técnico a la reconstrucción de los grupos humanos. Universidad del País Vasco, Bilbao, 269-285.

López-Sáez, J.A., López-García, P., López-Merino, L. 2006. El impacto humano en la Cordillera Cantábrica: Estudios palinológicos durante el Holoceno Medio. In: J.M. Maíllo-Fernández, E. Baquedano-Pérez (Eds.), Miscelánea en homenaje a Victoria Cabrera. Museo Arqueológico Regional de Madrid (Zona Arqueológica; 7-I), Alcalá de Henares, pp. 123-130.

López-Sáez, J.A., López-Merino, L., Pérez-Díaz, S., Parcero-Oubiña, C., Criado-Boado, F. 2009. Contribución a la caracterización de los espacios agrarios castreños: documentación y análisis palinológico de una posible terraza de cultivo en el castro de Follente (Caldas de Reis, Pontevedra). Trabajos de Prehistoria 66 (2), 171-182. https://doi.org/10.3989/tp.2009.09020.

Marín-Suárez, C. 2011 a. De nómadas a castreños. Arqueología del primer milenio antes de la era en el sector centro-occidental cantábrico. Department of Prehistory, Complutense University of Madrid (Unpublished PhD dissertation). http://eprints.ucm.es/14435/.

Marín-Suárez, C. 2011b. Las montañas cantábricas en el II y I milenio a.C.: un espacio de encuentro entre los grupos cantábricos y meseteños. In: Actas de las II Jornadas de Jóvenes en Investigación Arqueológica (Madrid, 6, 7 y 8 de mayo de 2009). JIA 2009, Tomo I. Pórtico, Zaragoza, pp. 137-145.

Marín-Suárez, C., González-Álvarez, D. 2011. La romanización del Occidente Cantábrico: de la violencia física a la violencia simbólica. Férvedes 7, 197-206.

Martínez-Cortizas, A., Costa-Casais, M., López-Sáez, J.A. 2009. Environmental change in NW Iberia between 7000 and $500 \mathrm{cal}$ BC. Quaternary International 200 (1-2), 77-89. https://doi. org/10.1016/j.quaint.2008.07.012.

Martínez-Cortizas, A., López-Merino, L., Bindler, R., Mighall, T., Kylander, M. 2016. Early atmospheric metal pollution provides evidence for Chalcolithic/Bronze Age mining and metallurgy in Southwestern Europe. Science of the Total Environment 545-546, 398-406. https://doi.org/10.1016/j.scitotenv.2015.12.078.

Mazier, F., Galop, D., Gaillard, M.J., Rendu, C., Cugny, C., Legaz, A., Peyron, O., Buttler, A. 2009. Multidisciplinary approach to reconstructing local pastoral activities: an example from the Pyrenean Mountains (Pays Basque). The Holocene 19 (2), 171-188. https://doi. org/10.1177/0959683608098956.

Menéndez-Blanco, A., Álvarez-Martínez, V., González-Álvarez, D. 2018. Escavación d’una estructura de combustión del cambeo d’Era n'Almoñu (Ayande). In: P. León (Ed.), Excavaciones Arqueológicas en Asturias 2013-2016. Principado de Asturias; Ediciones Trabe, Oviedo, 253-260. 
Montes-López, R. 2015. Intervenciones arqueológicas realizadas con motivo del seguimiento de las obras de saneamiento y EDAR de Proaza y Santo Adriano. Cuadiernu: Difusión, investigación y conservación del patrimonio cultural 3, 99-125.

Moore, J.(Ed.) 2016. Anthropocene or Capitalocene? Nature, History, and the Crisis of Capitalism. PM Press, Oakland.

Moreno, A., López-Merino, L., Leira, M., Marco-Barba, J., González-Sampériz, P., Valero-Garcés, B.L., López-Sáez, J.A., Santos, L., Mata, P., Ito, E. 2011. Revealing the last 13,500 years of environmental history from the multiproxy record of a mountain lake (Lago Enol, northern Iberian Peninsula). Journal of Paleolimnology 46 (3), 327-349. https://doi.org/10.1007/ s10933-009-9387-7.

Orengo, H.A., Palet, J.M., Ejarque, A., Miras, Y., Riera-Mora, S. 2013. The historical configuration of a high mountain UNESCO World Heritage Site: the agropastoral Cultural Landscape of Madriu-Perafita-Claror Valley. In: A.M. Stagno (Ed.), Montagne Incise. Pietre Incise. Archeologia delle risorse nella montagna mediterranea. Atti del Convegno (Borzonasca, 20-22 ottobre 2011). All'Insegna del Giglio (Archeologia Postmedievale; 17), Genova, pp. 333-343.

Parcero-Oubiña, C. 2006. Los paisajes agrarios castreños. Modelos de construcción del espacio agrario a lo largo de la Edad del Hierro del noroeste. Arqueología Espacial 26, 57-85.

Parcero-Oubiña, C., Ayán-Vila, X.M., Fábrega-Álvarez, P., Teira-Brión, A.M. 2007. Arqueología, Paisaje y Sociedad. In: F.J. González-García (Ed.), Los pueblos de la Galicia céltica. Akal, Madrid, pp. 131-258.

Parcero-Oubiña, C., Criado-Boado, F. 2013. Social Change, Social Resistance: A Long-Term Approach to the Processes of Transformation of Social Landscapes in the Northwest Iberian Peninsula. In: M. Cruz-Berrocal, L. García-Sanjuán, A. Gilman (Eds.), The Prehistory of Iberia. Debating Early Social Stratification and the State. Routledge, London, pp. 249-266.

Peña-Chocarro, L., Zapata-Peña, L., Iriarte-Chiapusso, M.J., González-Morales, M.R., Straus, L.G. 2005. The oldest agriculture in northern Atlantic Spain: new evidence from El Mirón Cave (Ramales de la Victoria, Cantabria). Journal of Archaeological Science 32 (4), 579587. https://doi.org/10.1016/j.jas.2004.12.001.

Prieto-Martínez, M.P., Mañana-Borrazás, P., Costa-Casais, M., Criado-Boado, F., López-Sáez, J.A., Carrión-Marco, Y., Martínez-Cortizas, A. 2012. Galicia. In: M.A. Rojo-Guerra, R. Garrido-Pena, I. García-Martínez de Lagrán (Eds.), El Neolítico en la Península Ibérica y su contexto europeo. Cátedra, Madrid, pp. 255-290.

Rendu, C. 2003. La Montagne d'Enveig. Une estive pyrénéenne dans la longue durée. Trabucaire, Canet.

Ruiz-Gálvez, M. 1998. La Europa Atlántica en la Edad del Bronce. Crítica, Barcelona.

Salas, J. 2016. Bienvenidos al Antropoceno: "Ya hemos cambiado el ciclo natural de la Tierra", El País 09/09/2016. https://elpais.com/elpais/2016/09/05/ciencia/1473092509_973513.html (last access: 14/08/2018).

Sastre, I. 2001 . Las formaciones sociales rurales de la Asturia romana. Ediciones Clásicas, Madrid. Scarre, C. 2002. Monuments and Landscape in Atlantic Europe. Perception and Society during the Neolithic and Early Bronze Age. Routledge, London.

Sherratt, A. 1983. The secondary exploitation of animals in the Old World. World Archaeology 15 (1), 90-104. https://doi.org/10.1080/00438243.1983.9979887.

Solli, B., Burström, M., Domanska, E., Edgeworth, M., González-Ruibal, A., Holtorf, C., Lucas, G., Oestigaard, T., Smith, L., Witmore, C. 2011. Some Reflections on Heritage and Archaeology in the Anthropocene. Norwegian Archaeological Review 44 (1), 40-88. https://doi.org/10.10 80/00293652.2011.572677.

Thomas, J. 2001. Archaeologies of Place and Landscape. In: Hodder, I. (Ed.), Archaeological Theory Today. Blackwell Publishers Ltd.; Polity Press, Malden, 165-186. 
Vázquez-Varela, J.M. 2001. El contraste ecológico promueve la comunicación entre las culturas: nuevos datos sobre los pastores trashumantes en A Serra de Ancares (Lugo y León). Semata: Ciencias Sociais e Humanidades 13, 251-260.

Villa-Valdés, A. 2007. Mil años de poblados fortificados en Asturias (siglos IX a.C.-II d.C.). In: J. Fernández-Tresguerres (Ed.), Astures y romanos: nuevas perspectivas. Real Instituto de Estudios Asturianos, Oviedo, 27-60.

Walsh, K. 2014. The Archaeology of Mediterranean Landscapes. Human-Environment Interaction from the Neolithic to the Roman Period. Cambridge University Press, Cambridge.

Walsh, K., Richer, S., de Beaulieu, J-L. 2006. Attitudes to altitude: changing meanings and perceptions within a 'marginal' Alpine landscape - the integration of palaeoecological and archaeological data in a high-altitude landscape in the French Alps. World Archaeology 38 (3), 436-454. https://doi.org/10.1080/00438240600813392.

Waters, C.N., Zalasiewicz, J., Summerhayes, C., Barnosky, A.D., Poirier, C., Gałuszka, A., Cearreta, A., Edgeworth, M., Ellis, E.C., Ellis, M., Jeandel, C., Leinfelder, R., McNeill, J. R., Richter, D., Steffen, W., Syvitski, J., Vidas, D., Wagreich, M., Williams, M., Zhisheng, A., Grinevald, J., Odada, E., Oreskes, N., Wolfe, A.P. 2016. The Anthropocene is functionally and stratigraphically distinct from the Holocene. Science 351 (6269). https://doi.org/10.1126/ science.aad2622.

Zalasiewicz, J., Williams, M., Steffen, W., Crutzen,P.J.2010. The New World of the Anthropocene. Environmental Science \& Technology 44 (7), 2228-2231. https://doi.org/10.1021/es903118j. 